\title{
ANTIFUNGAL DERIVATIVES FROM Piper mollicomum AND P. lhotzkyanum (PIPERACEAE)
}

\author{
João Henrique G. Lago* \\ Centro de Ciências e Humanidades, Universidade Presbiteriana Mackenzie, 01302-907 São Paulo - SP, Brasil \\ Maria Claudia M. Young \\ Seção de Fisiologia e Bioquímica de Plantas, Instituto de Botânica, CP 3005, 01061-970 São Paulo - SP, Brasil \\ Juliana B. Reigada, Marisi G. Soares, Bianca P. Roesler and Massuo J. Kato \\ Instituto de Química, Universidade de São Paulo, CP 26077, 05513-970 São Paulo - SP, Brasil
}

Recebido em 28/7/06; aceito em 9/3/07; publicado na web em 24/7/07

\begin{abstract}
Bioguided fractionation of the extracts from leaves of Piper mollicomum and Piper lhotzkyanum against the fungi Cladosporium cladosporioides and $\mathrm{C}$. sphaerospermum afforded seven bioactive compounds, four being chromenes: methyl 2,2-dimethyl- $2 \mathrm{H}$ chromene-6-carboxylate, methyl 8-hydroxy-2,2-dimethyl-2H-chromene-6-carboxylate, 2-methyl-2-[4'-methyl-3'-pentenyl]-2H-1benzopyran-6-carboxylic acid, 2,2-dimethyl-2H-chromene-6-carboxylic acid, one a dihydrochalcone: 2',6'-dihydroxy-4'methoxydihydrochalcone, and two flavanones: 7-methoxy-5,4'-dihydroxy-flavanone and 7,4'-dimethoxy-5-hydroxy-flavanone. The structures of the bioactive isolated derivatives were elucidated by interpretation of their NMR data $\left[{ }^{1} \mathrm{H}\right.$ and $\left.{ }^{13} \mathrm{C}\left(\mathrm{BBD}, \mathrm{DEPT} 135^{\circ}\right)\right]$, and mass spectral data as well as by comparison with data described in the literature.
\end{abstract}

Keywords: Piper mollicomum; Piper lhotzkyanum; antifungal derivatives.

\section{INTRODUCTION}

Phytochemical studies on Piper species describe the isolation of several classes of metabolites including amides, flavonoids, chromenes, lignans, benzoic acids, and phenylpropanoids. ${ }^{1}$

Piper mollicomum Kunth. and P. lhotzkyanum Kunth. belong to the Piperaceae family and are distributed in Brazil, in the Amazon region and the Atlantic Forrest. ${ }^{2}$ A previous investigation of $P$. lhotzkyanum afforded one chromene, two prenylated benzoic acids, six sesquiterpenoids, and phytol. ${ }^{3}$ Another study with this plant described the isolation and characterization of a $C$-glucosylflavone, four phenylpropanoid derivatives, and one flavanone. ${ }^{4}$ No phytochemical studies were found for P. mollicomum, in exception the volatile oil composition. ${ }^{5}$ However, no report about the antifungal potential to these species has been described in literature.

In this paper we describe the isolation, characterization and evaluation of antifungal potential of two chromenes (1 and 2) and one dihydrochalcone (5) from P. mollicomum, and two chromenes (3 and 4) and two flavanones (6 and 7) from P. lhotzkyanum.

\section{RESULTS AND DISCUSSION}

The structures of compounds $\mathbf{1}-\mathbf{7}$ were deduced by interpretation of their NMR data $\left[{ }^{1} \mathrm{H}\right.$ and ${ }^{13} \mathrm{C}\left(\mathrm{BBD}\right.$ and DEPT $\left.\left.135^{\circ}\right)\right]$ and mass spectral data as well as by comparison of the data described in the literature.

The ${ }^{13} \mathrm{C}$ NMR spectra of $\mathbf{1} \mathbf{- 4}$ showed aromatic carbon peaks at $\delta 115.9-156.9$ and carbinolic carbons at $\delta 77.2-79.9$ (C), which in association to intense peak at $\delta 28.4\left(2 \mathrm{X} \mathrm{CH}_{3}\right)$ and $\mathrm{sp}^{2}$ carbons at $\delta 127.9-131.0(\mathrm{CH})$ and $121.5-121.4(\mathrm{CH})$ suggested the occurrence of chromene derivatives. ${ }^{6}$ The presence of an 1,3,4trissubstituted aromatic ring to compounds $\mathbf{1}$ and $\mathbf{4}$ was defined by the presence, in their ${ }^{1} \mathrm{H}$ NMR spectra, of three signals at $\delta 6.80(\mathrm{~d}$, $J=8.7 \mathrm{~Hz}), \delta 7.70(\mathrm{~d}, J=1.5 \mathrm{~Hz})$ and $\delta 7.85(\mathrm{dd}, J=8.7$ and 1.5

*e-mail: joaolago@iq.usp.br<smiles>[R]OC(=O)c1cc([R])c2c(c1)C=CC([R])(C)O2</smiles>

$$
\begin{aligned}
& 1 \mathrm{R}_{1}=\mathrm{Me} ; \mathrm{R}_{2}=\mathrm{H} ; \mathrm{R}_{3}=\mathrm{Me}(\mathrm{C}-10) ; \\
& 2 \mathrm{R}_{1}=\mathrm{Me} ; \mathrm{R}_{2}=\mathrm{OH} ; \mathrm{R}_{3}=\mathrm{Me}(\mathrm{C}-10) ; \\
& 3 \mathrm{R}_{1}=\mathrm{H} ; \mathrm{R}_{2}=\mathrm{H} ; \mathrm{R}_{3}= \\
& 4 \mathrm{R}_{1}=\mathrm{H} ; \mathrm{R}_{2}=\mathrm{H} ; \mathrm{R}_{3}=\mathrm{Me}(\mathrm{C}-10)
\end{aligned}
$$<smiles>COc1cc(O)c(C(=O)CCc2ccccc2)c(O)c1</smiles>

$$
5
$$<smiles>[R]Oc1ccc([C@H]2CC(=O)c3c(O)cc(OC)cc3O2)cc1</smiles>

$6 \mathrm{R}=\mathrm{H}$

$7 \mathrm{R}=\mathrm{Me}$
Figure 1. Chromenes, dihydrochalcone and flavanones isolated from Piper mollicomum and P. lhotzkyanum

$\mathrm{Hz}$ ) assigned to $\mathrm{H}-8, \mathrm{H}-5$ and $\mathrm{H}-7$, respectively. As in the ${ }^{1} \mathrm{H}$ NMR spectrum of 1 was observed an intense peak at $\delta 3.87\left(\mathrm{OCH}_{3}\right)$, this compound was elucidated as the methyl ester of 4 . Thus, compounds $\mathbf{1}$ and $\mathbf{4}$ were identified as methyl 2,2-dimethyl-2H-chromene-6carboxylate $^{6}$ and 2,2-dimethyl- $2 H$-chromene-6-carboxylic acid, ${ }^{7}$ respectively. Similarly, the ${ }^{1} \mathrm{H}$ NMR spectrum of $\mathbf{3}$ indicated the same 1,3,4-trissubstituted aromatic ring. The additional signals at $\delta 1.68$ (s, 3H, H-5'), 1.58 (s, 3H, H-6'), 2.10 (m, 2H, H-2'), 1.80 (t, $\left.J=7.4 \mathrm{~Hz}, \mathrm{H}-1^{\prime}\right)$ and 5.10 (m, 1H, H-3') suggested a 4'-methyl-3'pentenyl substitution. As the singlet at $\delta 1.44(3 \mathrm{H})$ was assigned to $\mathrm{H}-9$, it is in the carbinolic carbon C-2. The comparison of ${ }^{1} \mathrm{H}$ and ${ }^{13} \mathrm{C}$ NMR data with those reported in the literature ${ }^{3,8}$ allowed the 
identification of $\mathbf{3}$ as 2-methyl-2-[4'-methyl-3'-pentenyl]-2H-1benzopyran-6-carboxylic acid. The ${ }^{1} \mathrm{H}$ NMR of $\mathbf{2}$ showed two doublets at $\delta 7.33(J=1.8 \mathrm{~Hz})$ and $7.48(J=1.8 \mathrm{~Hz})$, which were indicative of a 1,2,3,5-tetrasubstituted aromatic ring. The remaining NMR data, in association to LREIMS, which showed the molecular ion-peak at $m / z, 234$, suggested an additional hydroxyl group. Since the aromatic hydrogens were positioned in meta, this group was attached at C-8, which was confirmed by signal at $\delta 143.4$ (C) in the ${ }^{13} \mathrm{C}$ NMR spectra, characteristic of an aromatic carbinolic carbon. Therefore, this compound was identified as methyl 8 hydroxy-2,2-dimethyl- $2 \mathrm{H}$-chromene-6-carboxylate. ${ }^{9}$

The ${ }^{1} \mathrm{H}$ NMR spectrum of $\mathbf{5}$ showed two triplets at $\delta 3.02(\mathrm{~J}=$ $7.3 \mathrm{~Hz}, 2 \mathrm{H})$ and $3.40(J=7.3 \mathrm{~Hz}, 2 \mathrm{H})$. These signals associated to multiplet at $\delta 7.1-7.3(5 \mathrm{H})$ and a peak at $\delta 5.91(2 \mathrm{H})$ suggested the occurrence of a dihydrochalcone. Signals referring to carbonyl group at $\delta 204.5(\mathrm{C}=\mathrm{O})$, aromatic group at $\delta 94.5-165.6$ despite of aliphatic carbons at $\delta 45.6\left(\mathrm{CH}_{2}\right), 30.5\left(\mathrm{CH}_{2}\right)$ and $55.5\left(\mathrm{CH}_{3}\right)$, in the ${ }^{13} \mathrm{C}$ NMR spectra (BBD and DEPT $\left.135^{\circ}\right)$, confirms the structural arrangement of $\mathbf{5}$ as 2',6'-dihydroxy-4'-methoxydihydrochalcone. ${ }^{10}$

In the both ${ }^{1} \mathrm{H}$ NMR spectra of $\mathbf{6}$ and $\mathbf{7}$ were observed $\mathrm{AB}$ systems at $\delta 6.95(\mathrm{~d}, J=8.7 \mathrm{~Hz})$ and $7.37(\mathrm{~d}, J=8.7 \mathrm{~Hz})$, characteristic of para-dissustituted aromatic ring, and two doublets at $\delta 6.02(J=2.4$ $\mathrm{Hz}, 1 \mathrm{H})$ and $6.10(J=2.4 \mathrm{~Hz}, 1 \mathrm{H})$ indicative of a $1,2,3,5-$ tetrassubstituted aromatic ring. These data, associated to the signals at $\delta 5.33(\mathrm{dd}, J=13.0$ and $2.9 \mathrm{~Hz}, \mathrm{H}-2), 2.75(\mathrm{dd}, J=17.0$ and 2.9 $\mathrm{Hz}, \mathrm{H}-3 \mathrm{a}$ ), 3.07 (dd, $J=17.0$ and $13.0 \mathrm{~Hz}, \mathrm{H}-3 \mathrm{~b}$ ) and $\delta 12.6$ (s, hydroxyl group chelated to carbonyl group) are characteristic of 5hydroxy-flavanone derivatives. ${ }^{11}$ LREIMS analysis showed molecular ion-peaks at $m / z, 286\left(\mathrm{C}_{16} \mathrm{H}_{14} \mathrm{O}_{5}\right.$ - compound 6) and $300\left(\mathrm{C}_{17} \mathrm{H}_{16} \mathrm{O}_{5}\right.$ compound 7). These spectra showed also RDA fragmentation ion peaks at $\mathrm{m} / \mathrm{z}, 166$ to both derivatives and peaks at $\mathrm{m} / \mathrm{z}, 120$ and $\mathrm{m} / \mathrm{z}$ 134 to 6 and 7, respectively. This analysis confirms the presence of an additional methoxyl group at C-4' in 7. Finally, compounds 6 and 7 were identified as 7-methoxy-5,4'-dihydroxy-flavanone and 7,4'dimethoxy-5-hydroxy-flavanone, respectively. ${ }^{11-13}$

The occurrence of chromenes was described to $P$. aduncum,,$^{2,7,9,14}$ $P$. taboganum, ${ }^{15} P$. dilatatum, ${ }^{16}$ and $P$. lhotzkyanum, ${ }^{2}$ while the occurrence of flavanones was reported to $P$. hostmanianum, ${ }^{6,17} P$. hispidum, ${ }^{18-20}$ P. carniconnectivum,${ }^{21} P$. aduncum, ${ }^{19,20,22} P$. fadyenii, ${ }^{20}$ P. steerni, ${ }^{17}$ P. crassinervium, ${ }^{4,23} P$. lhotzkyanum, ${ }^{3}$ and $P$. methysticum. ${ }^{24,25}$ Despite the high distribution of flavanones ${ }^{26}$, the presence of dihydrochalcones in the genus Piper has been restricted to $P$. aduncum, ${ }^{10,18-20,27-29}$ P. fadyenii, ${ }^{20}$ and $P$. hispidum. ${ }^{18-20}$

All of the isolated chromenes, dihydrochalcone, and flavanones are being reported here for the first time in P. mollicomum, since no phytochemical studies have previously been conducted with this species. Otherwise, although chromenes and flavonoids have previously been reported in P. lhotzkyanum, ${ }^{3,4}$ the occurrence of $\mathbf{4}$ and 7 has been described at first time in this species.

The minimum quantity of compounds $\mathbf{1}-\mathbf{7}$ necessary to inhibit growth of Cladosporium cladosporioides and C. sphaerospermum by means of direct bioautography assay, ${ }^{4,29}$ showed that $\mathbf{3 , 4}, \mathbf{5}$ and $\mathbf{6}$ were the most active (Table 1). As observed to $\mathbf{1}-\mathbf{4}$, the esterification of carboxyl group led to a decrease of the fungitoxic activity. Additional 4'-methyl-3'-pentenyl group in $\mathbf{3}$, in comparison to 4 , did not modify the antifungal potential while the presence of a hydroxyl group at $\mathrm{C}-8$ in $\mathbf{2}$, in comparison to $\mathbf{1}$, showed an enhancement of this potential. As showed in Table 1, the minimal amount of $\mathbf{6}$ to inhibit the growth both fungi were $1.0 \mu \mathrm{g}$, while to 7, which differ by the presence of an additional methyl group in B ring, these values decreased to $25.0 \mu \mathrm{g}$ to both fungi. These observations suggest important relationships between the structure of chromene or flavanone derivatives and the antifungal activity.
Table 1. Antifungal activity of compounds $\mathbf{1}$ - $\mathbf{7}$ against Cladosporium cladosporioides and $C$. sphaerospermum

\begin{tabular}{lcc}
\hline \multirow{2}{*}{ Compound } & \multicolumn{2}{c}{ Antifungal activity* $(\mu \mathrm{g})$} \\
\hline $\mathbf{1}$ & C. cladosporioides & C. sphaerospermum \\
$\mathbf{2}$ & 50.0 & 50.0 \\
$\mathbf{3}$ & 10.0 & 10.0 \\
$\mathbf{4}$ & 5.0 & 5.0 \\
$\mathbf{5}$ & 5.0 & 5.0 \\
$\mathbf{6}$ & 5.0 & 10.0 \\
$\mathbf{7}$ & 1.0 & 1.0 \\
Nystatin & 25.0 & 25.0 \\
Miconazole & 1.0 & 1.0 \\
\end{tabular}

*minimum amount required for the inhibition of fungal growth on thin-layer chromatographic plates (TLC).

\section{EXPERIMENTAL}

\section{General procedures}

Silica gel (Merck, 230-400 mesh) and Sephadex LH-20 (Sigma) were employed in the CC separations, whilst analytical TLC was performed using silica gel $60 \mathrm{PF}_{254}$ layers (Merck). ${ }^{1} \mathrm{H}$ and ${ }^{13} \mathrm{C} \mathrm{NMR}$ spectra (BBD - broad band decoupled and DEPT $135^{\circ}$ distortionless enhancement by polarization transfer) were measured at 300 and $75 \mathrm{MHz}$, respectively, on a Bruker model DPX-300 spectrometer with samples dissolved in $\mathrm{CDCl}_{3}$ (Aldrich). TMS was employed as internal standard: chemical shifts were recorded in $\mathrm{d}$ (ppm) and coupling constants $(J$ ) in Hz. LREIMS (low resolution electronic impact mass spectrometry) spectra were measured at 70 $\mathrm{eV}$ on Finnegan-Mat INCOS 50 quadrupole spectrometer.

\section{Plant material}

The plant material were collected at Ubatuba - SP, Brazil, on September, 2002 (Piper mollicomum) and at Poços de Caldas - MG, Brazil, on May, 2002 (Piper lhotzkyanum) and were identified by Dr. E. F. Guimarães (Jardim Botânico, Rio de Janeiro, Brazil). Voucher specimens (Kato-301 and Kato-226, respectively) have been deposited at the Herbarium of the Instituto de Botânica (SMA-SP).

\section{Extraction and isolation}

Dried and powdered leaves of P. mollicomum $(54 \mathrm{~g})$ were extracted by maceration with $\mathrm{MeOH}(3 \times 1 \mathrm{~L})$ at room temperature. The resulting solutions were concentrated in vacuum to yield a crude extract $(1.6 \mathrm{~g})$ which was evaluated to detection of antifungal potential. As this extract showed activity, it was subjected to column chromatography over silica gel (gradient of hexane to EtOAc and from EtOAc to $\mathrm{MeOH}$ ) yielding six fractions, in which fractions 2, 4 and 5 showed antifungal potential. Compound 1 was isolated in pure form from fraction $2(16 \mathrm{mg})$. Fraction 4 was further chromatographed on a silica gel column using gradient mixtures of EtOAc in hexane yielding three sub-fractions (I-III). Sub-fraction II (10 mg) was composed by pure 2 . Fraction 5 was subjected to column chromatography over silica gel (gradient of EtOAc in hexane and $\mathrm{MeOH}$ in EtOAc) yielding three sub-fractions (I-III). Compound 5 was isolated from active sub-fraction II ( $89 \mathrm{mg})$. The ${ }^{1} \mathrm{H}$ NMR spectra of the remaining fractions showed a predominance of fatty material.

Dried and powdered leaves of P. lhotzkyanum (112 g) were extracted with $\mathrm{MeOH}(3 \times 1.5 \mathrm{~L})$ at room temperature to afford a 
crude extract $(5.2 \mathrm{~g})$. This extract showed antifungal potential and was partitioned between $\mathrm{MeOH} / \mathrm{H}_{2} \mathrm{O}(1: 4)$ and $\mathrm{CH}_{2} \mathrm{Cl}_{2}$ to give apolar phase $(1.4 \mathrm{~g})$. NMR analysis of this phase indicated a predominance of fatty material. The hydro-methanol solution was partitioned with EtOAc to afford an EtOAc phase $(2.3 \mathrm{~g})$. After evaluation of antifungal potential, which was detected in the EtOAc phase, this was subjected to column chromatography over silica gel (gradient of hexane to EtOAc and from EtOAc to $\mathrm{MeOH}$ ) yielding five fractions. As the antifungal potential was detected in fraction 4 (490 mg), it was chromatographed on Sephadex LH-20 column, using $\mathrm{MeOH}$ as eluent to afford 3 (12 mg), 4 (23 mg), 6 (18 mg) and 7 (38 $\mathrm{mg})$.

\section{Antifungal assay}

The fungi used in this bioautographic assay Cladosporium cladosporioides and $C$. sphaerospermum have been maintained at the Instituto de Botânica, São Paulo - SP. Solutions corresponding to $100.0,50.0,25.0,10.0,5.0,1.0 \mu \mathrm{g}$ of pure compounds were applied to TLC plates which were sprayed with a spore suspension of fungi. After incubation for $48 \mathrm{~h}$ in darkness in a moistened chamber at $25{ }^{\circ} \mathrm{C}$, a clear inhibition zone appeared to indicate minimal amount of tested compounds. ${ }^{8,29}$

\section{ACKNOWLEDGMENTS}

The authors are grateful to FAPESP, CNPq and MackPesquisa to financial support and fellowships.

\section{REFERENCES}

1. Parmar, V. S.; Jain, S. C.; Bisht, K. S.; Jain, R.; Taneja, P.; Jha, A.; Tyagi, O. D.; Prasad, A. K.; Wengel, J.; Olsen, C. E.; Boll, P. M.; Phytochemistry 1997, 46, 597.

2. Ribeiro, J. E. L. da S.; Hopkins, M. J. G.; Vincentin, A.; Sothers, C. A.; Costa, M. A. da S.; de Brito, J. M.; de Souza, M. A. D.; Martins, L. H. P.; Lohmann, L. G.; Assunção, P. A. C. L.; Pereira, E. de C.; Mesquita, M. R.; Procópio, L. C.; Flora da Reversa Ducke - Guia de identificação das plantas vasculares de uma floresta de terra-firme da Amazônia Central, INPA-DFID: Manaus, 1999.
3. Moreira, D. L.; Guimarães, E. F.; Kaplan, M. A. C.; Phytochemistry 1998 , 49, 1339.

4. Moreira, D. L.; Guimarães, E. F.; Kaplan, M. A. C.; Phytochemistry 2000, $55,783$.

5. Santos, P. R. D.; Moreira, D. L.; Guimarães, E. F.; Kaplan, M. A. C.; Phytochemistry 2001, 58, 547.

6. Diaz, P. P.; Arias, T.; Joseph-Nathan, P.; Phytochemistry 1987, 26, 809.

7. Baldoqui, D. C.; Kato, M. J.; Cavalheiro, A. J.; Bolzani, V. S.; Young, M. C. M.; Furlan, M.; Phytochemistry 1999, 51, 899.

8. Lago, J. H. G.; Ramos, C. S.; Casanova, D. C. C.; Morandin, A. A.; Bergamo, D. C. B.; Furlan, M.; Cavalheiro, A. J.; Bolzani, V. da S.; Young, M. C. M.; Guimarães, E. F.; Kato, M. J.; J. Nat. Prod. 2004, 67, 1783.

9. Orjala, J.; Erdelmeier, C. A. J.; Wright, A. D.; Rali, T.; Sticher, O.; Phytochemistry 1993, 34, 813.

10. Orjala, J.; Wright, A. D.; Behrends, H.; Folkers, G.; Sticher, O.; Ruegger, H.; Rali, T.; J. Nat. Prod. 1994, 57, 18.

11. McCormick, S.; Robson, K.; Bohm, B.; Phytochemistry 1986, 25, 1723.

12. Duddeck, H.; Snatzne, G.; Yemul, S. S.; Phytochemistry 1978, 17, 1369.

13. Niwa, M.; Otsuji, S.; Tatematsu, H.; Liu, G. C.; Chen, X. F.; Hirata, Y.; Chem. Pharm. Bull. 1986, 34, 3249.

14. Diaz, D.; Pedro, P.; Maldonado, E.; Ospina, E.; Rev. Latinoamer. Quim. 1984, 15, 136.

15. Roussis, V.; Ampofo, S. A. ; Wiemer, D. F. ; Phytochemistry 1990, 29, 1787.

16. Terreaux, C. ; Gupta, M. P. ; Hostettmann, K. ; Phytochemistry 1998, 49, 461.

17. Posso, O. R.; Diaz, P. P.; de Diaz, A. M. P.; Rev. Colomb. Quim. 1994, 23, 53.

18. Vieira, P. C.; Alvarenga, M. A.; Gottlieb, O. R.; Gottlieb, H. E.; Planta Med. 1980, 39, 153.

19. Burke, B.; Nair, M.; Phytochemistry 1986, 25, 1427.

20. Nair, M. G.; Masingh, A. P.; Burke, B. A.; Agr. Biol. Chem. 1986, 50, 3053.

21. Facundo, V. A.; Ferreira, S. A.; Sa, A. L.; Matos, C. R. R.; Braz-Filho, R.; J. Braz. Chem. Soc. 2004, 15, 140.

22. Dutta, C. P.; Som, U. K.; J. Indian Chem. Soc. 1978, 55, 932.

23. Danelutte, A. P.; Lago, J. H. G.; Young, M. C. M.; Kato, M. J.; Phytochemistry 2003, 64, 555.

24. Prabhu, R. B.; Mulchandani, B. N.; Phytochemistry 1985, 24, 329.

25. Rao, J. M.; Subramanyam, K. V. J.; Curr. Sci. 1974, 43, 76.

26. Parmar, V. S.; Jain, S. C.; Gupta, S.; Talwar, S.; Rajwanshi, V. K.; Kumar, R.; Azim, A.; Malhotra, S.; Kumar, N.; Jain, R.; Sharma, N. K.; Tyagi, O. D.; Lawrie, S. J.; Errington, W.; Howarth, O. W.; Olsen, C. E.; Singh S. K.; Wengel, J.; Phytochemistry 1998, 49, 1096.

27. Orjala, J.; Wright, A. D.; Erdelmeier, C. A. J.; Sticher, O.; Rali, T.; Helvet. Chim. Acta 1993, 76, 1481.

28. Achenbach, H.; Cale, A. D.; Maussa, D.; Poveda, C.; Rev. Mex. Cienc. Farm. 1984, 14, 2.

29. Homans, A. L.; Fuchs, A.; J. Chromatogr. 1970, 51, 327. 